\title{
George D. Herron in the 1890s: A New Frame of Reference for the Study of the Progressive Era
}

Robert M. Crunden

IN THE EARLY 1950s, Richard Hofstadter studied the more -prominent leaders of progressive opinion during the early years of the twentieth century, and announced that these men were progressives "not because of economic deprivations but primarily because they were victims of an upheaval in status that took place in the United States" during the late nineteenth and early twentieth centuries. Progressivism, he concluded, "was to a very considerable extent led by men who suffered from the events of their time not through a shrinkage in their means but through the changed pattern in the distribution of deference and power." Other influential studies seemed to support Hofstadter's views, and few historians would deny that for the decade after its publication, Hofstadter's The Age of Reform dominated interpretations of this period. ${ }^{1}$

The result of this conceptual domination was a whole generation of younger historians who felt that they had to refute or refine the "status resentment" analytical framework in order to get on with their monographic work. Robert Wiebe and Samuel Hays argued for more complex sociological models and stressed the impacts of industrialization and urbanism. J. J. Huthmacher and John D. Buenker found that lower class and immigrant groups contributed substantially to legislative innovation during the period. A large number of historians took small parts of progressive activity to analyze with Hofstadter in mind, and concluded that status

\footnotetext{
${ }^{1}$ Richard Hofstadter, The Age of Reform, (N.Y., 1955), 135. See also George Mowry, The California Progressives, (Chicago, 1963, c. 1951), and Alfred D. Chandler, Jr., "The Origins of Progressive Leadership," in Elting E. Morison, ed., The Letters of Theodore Roosevelt, (Cambridge, 1954), Vol. 8.
} 
resentment did not really play all that large a role, that conservatives were in largely similar circumstances, and that the Hofstadter model simply could not hold up after detailed examination. By 1970, the wreckage of his thesis had become a roadblock to further useful study of the period, and at least one historian had concluded that there was no such thing as a Progressive Movement. ${ }^{2}$

Historians are not always followers of the history of the theater, but this whole, generation-long argument about status resentment can be summed up tidily by the following anecdote which used to be in the repertoire of Munich commedian Karl Vallentin. The curtain rises to a dark stage, and in the darkness a street lamp casts a single ray of light. Vallentin, looking very worried, walks around and around desperately looking for something in the circle of light. A policeman arrives and asks him what he has lost.

"The key to my house."

They search together for a while, finding nothing, and finally the policeman asks, "Are you sure you lost it here?"

"No," came the answer, as Vallentin pointed to a dark corner some distance from the light. "Over there."

"Then why on earth are you looking for it here?"

"There is no light over there."

Historians by now can safely say that they have searched the area illuminated by the thesis of status resentment, and have not found the key to the period. It is time to abandon it, and at least try another light, and use it in another corner. It is with this intention that I offer the essay that follows.

${ }^{2}$ Robert Wiebe, The Search For Order, 1877-1920, (N.Y.,1967); Samuel P. Hays, The Response to Industrialism, 1885-1914, (Chicago, 1957), and "The Social Analysis of American Political History, 1880-1920," Political Science Quarterly, LXXX, (Summer, 1965), \#3, 373-94; Hays also cites upper class support for reform in "The Politics of Reform in Municipal Government in the Progressive Era," Pacific Northwest Quarterly, LV (October, 1964), 157-69; J. Joseph Huthmacher, "Urban Liberalism and the Age of Reform," Mississippi Valley Historical Review, XLIV, (September, 1962), 321-41; John D. Buenker, "Urban Immigrant Lawmakers and Progressive Reform in Illinois," in Donald F. Tingley, ed., Essays in Illinois History, (Carbondale, 1968), 52-74; David P. Thelen, "Social Tensions and the Origins of Progressivism," Journal of American History, LVI, \#2, (September, 1969), 323-41; Peter Filene, "An Obituary for 'The Progressive Movement,' " American Quarterly, XXII, (1970), 20-34.

${ }^{3}$ I have followed the version given in Erich Heller, The Disinherited Mind, (London, 1952), 196. 
My point of departure is the single most perceptive paragraph in the well-known memoirs of Frederic C. Howe. After detailing his rigidly evangelical background, Howe went on to describe what this religious background did to his well-known career as a progressive reformer:

Physical escape from the embraces of evangelical religion did not mean moral escape. From that religion my reason was never emancipated. By it I was conformed to my generation and made to share its moral standards and ideals. It was with difficulty that realism got lodgment in my mind; early assumptions as to virtue and vice, goodness and evil remained in my mind long after I had tried to discard them. This is, I think, the most characteristic influence of my generation. It explains the nature of our reforms, the regulatory legislation in morals and economics, our belief in men rather than in institutions and our messages to other peoples. Missionaries and battleships, anti-saloon leagues and Ku Klux Klans, Wilson and Santo Domingo are all a part of that evangelistic psychology that makes America what she is. ${ }^{4}$

A few historians have already begun to analyze the Progressive Era in terms of its religious framework. Most scholars in the field have long recognized the importance of American Protestantism in forming the world views of leading progressives, but no one really has seen what I believe to be the case, that child-rearing in a devoutly Protestant home was probably the one key psychological experience common to the vast majority of progressives. Because, quite often, those who were not progressives had similar upbringings, it proved to be possible to conduct entire political, economic and sociological arguments along what were really theological and ethical lines, and it is this persistent ethicism that distinguishes the Progressive Era from, most obviously, the New Deal. The Progressive Era was thus not chiefly a period of status resentment, social tensions, or a recognizable movement; it was rather the period in which Christian people of evangelical Protestant background came to terms with modern industrial and social conditions. That is why the outwardly political and economic debates of the period seem so righteous, so moralistic and even priggish to modern students. That is also why a light like status resentment does not illumine satisfactorily. ${ }^{5}$

\footnotetext{
${ }^{4}$ Frederic C. Howe, The Confessions of A Reformer. (N.Y., 1925), 16-17.

${ }^{5} \mathrm{See}$, for example, the excellent recent synthesis, Clyde" Griffen, "The Progressive Ethos," in Stanley Coben and Lorman Ratner, eds., The Development of An American Culture, (Englewood Cliffs, 1970), 120-49; and Robert M. Crunden, A Hero In Spite of Himself: Brand Whitlock in Art, Politics and War, (N.Y.,1969).
} 
We need, then, to redefine the basic tasks of the period. Instead of "progressive leadership" always implying political and economic leaders, it should imply innovative behavior in all areas of the culture. A more complex and true picture of evangelical progressivism should include disciplines like philosophy, architecture, education, journalism, social work, and most obviously in terms of this essay, religion itself.

Likewise, we need to reassess the conventional barriers that often appear between populism, progressivism, and socialism in historiography. If, in fact, evangelical religion is important, then each of these terms would probably imply only a variation on a religious and not a political theme. As we shall see, George Herron's career is especially useful here, since he was actively involved in all three of these areas, and for the same religious reasons.

Finally, if character development and not voting patterns is as important as I suggest, then some use of psychology may well be warranted. As most psychoanalytical writers willingly point out, the tools of psychology do not permit predictability in any scientific sense, and predictability is what most recent analyzers of the period wish above all. But modern religious psychology has given us terms and a frame of reference that help to clarify individual development, and in particular the development of the superego during childhood will be of particular importance in trying to define what, for example, caused Frederic Howe, or George Herron-or Woodrow Wilson or any other progressive-to conceive apparently nonreligious issues in religious terms.

II

The career of George D. Herron was hardly typical of social gospel ministers, but no one was really typical of this remarkably disparate group of men. We have a detailed study of only a few reform clergy during this period, but if we combine these biographies with the few general studies available, ${ }^{6}$ Herron appears in this company to have been, for a while, the most popular, the most

6 James Dombrowski, The Early Days of Christian Socialism in America, (N.Y.,1936), was a pioneer study but is too tentative and inaccurate to be of much use today. Modern scholarship really began with $\mathrm{C}$. Howard Hopkins, The Rise of the Social Gospel in American Protestantism, 1865-1915, (New Haven, 1940). Subsequent studies of continuing value are Dores R. Sharpe, Walter Rauschenbusch, (N.Y., 1942), Aaron I. Abell, The Urban Impact on 
controversial, the most erratic, the most involved in politics, and ultimately the most despised among the general public. In the space of a decade, he touched on more politically and socially sensitive areas than any of the other reform clergy, and his sudden rise and fall enable us to examine the boundaries of permissible religious dissent in America before World War One.?

George Davis Herron was born on January 21, 1862, the son of William and Isabella Herron, of Montezuma, Indiana. Herron's own account of these years, written in 1891, is virtually the only primary source, and it is insistent on the strictly religious nature of his home and upbringing. Through his father, "a humble man who believed the Bible and hated unrighteousness," he came "from an unbroken line of Christian ancestors, reaching back to the days of the Scottish Reformation." His mother, while pregnant with George, prayed constantly that her child would be a servant of God. "She received me as from God and gave me back to God as her free-will offering. She besought God to keep me upon the altar of a perfect sacrifice in

American Protestantism, 1865-1900, (Cambridge, 1943), Henry F. May, Pròtestant Churches and Industrial America, (N.Y.,1949), Ira V. Brown, Lyman Abbott Christian Evolutionist, (Cambridge, 1953), Jacob Dorn, Washington Gladden, (Columbus, 1967), and Dong-Bai Chai, Josiah Strong: Apostle of Anglo-Saxonism and Social Christianity, (Ph.D. thesis, University. of Texas, 1972). For parallel Catholic developments, see Aaron I. Abell, American Catholicism and Social Action: A Search for Social Justice, 1865-1950, (N.Y.,1960).

${ }^{7}$ There are four dissertations and three published articles that are basic to study of Herron. Mitchell P. Briggs, George D. Herron and the European Settlement, "Stanford University Publications in History, Economics and Political Science," Vol. III, \#2, (Stanford, 1932) deals almost entirely with World War I and its aftermath; Robert T. Handy, "George D. Herron and the Social Gospel in American Protestantism, 1890-1901, (Ph.D., University of Chicago Divinity School, 1949), deals chiefly with theology; Phyllis Ann Nelson, "George D. Herron and the Socialist Clergy, 1890-1914," (Ph.D., University of lowa, 1953), is a very long and detailed study of Herron's place in clerical socialism; Herbert R. Dieterich, "Patterns of Dissent: The Reform Ideas and Activities of George D. Herron," (Ph.D. thesis, University of New Mexico, 1957), is an admirably concise study of all Herron's career, and the only lengthy study using all of the available unpublished papers. I would like to thank Mr. Dieterich, of the University of Wyoming, for his bibliographical assistance to me at an early stage of my work. Three published articles developed from these dissertations are: Robert T. Handy, "George D.'Herron and the Kingdom Movement," Church History, XIX, \#2, (June, 1950), 97-115; H. R. Dieterich, "Radical on the Campus: Professor Herron at lowa College, 1893-1899," Annals of Iowa, XXXVII, \#6, (Fall, 1964), 401-15; and "Revivalist As Reformer-Implications of George D. Herron's Speaking," Quarterly Journal of Speech, (December, 1960), 391-399. 
the service of his Christ and her Redeemer." If Herron is correct, she never felt so exalted again in her generally unhappy life as during this period, because she felt that nothing she had done or could do would be as important to God as giving him a child consecrated to his service. ${ }^{8}$

IIIness apparently haunted the household. Herron was often thought to be near death, and his mother was an invalid most of the time. The child, as a result, had an unusual upbringing, having virtually no friends of his own age, and being entirely devoted to his father. "He taught me, very early, to read and selected my books, directed my thoughts. We were seldom apart, day or night. He drew out all there was in me and turned it Godward." George very early worked his way through a history of the world, and through at least portions of George Bancroft's history of America, and emerged with the predictable vision of history as the reign and plan of God. Herron "could not form a conception from any other point of view. An accident, in the minutest detail of life, was a thing foreign to my comprehension. I was a slave, if I may so speak, to the will of God." He had few friends, and so God and his historical heroes were Herron's imaginary playmates:

God was my confident. I never thought of myself as other than his child. I talked with him over my books and on my walks. He answered my prayers. The words and deeds of his servants were my recreation. Joseph, Elijah and Daniel, Cromwell and John Wesley and Charles Sumner, were my imaginary playmates. Thus I grew up in the company of God, with a daily deepening sense of a divine call which sooner or later I must obey.

The poverty of the family prevented anything like normal schooling. Herron worked in a printing office, working in what he later regarded as depraved and sinful circumstances. At about age seventeen, he decided to pursue a more formal education, and entered the preparatory school part of Ripon College, in Wisconsin, in 1879. After less than two years, ill health, poverty and only mediocre scholastic success caused him to drop out, and he worked briefly for a Ripon newspaper. Despite his rather dismal prospects,

${ }^{8}$ This and subsequent early biographical data, unless otherwise specified, is from George D. Herron, "The Confession of Faith," from the Burlington Hawkeye December 31, 1891, pp. 2, 4. I have used the archives of Grinnell College for this and much other newspaper and magazine material, and would like to thank Mrs. Mary E. Klausner, the research librarian, for her help in showing me through this collection. 


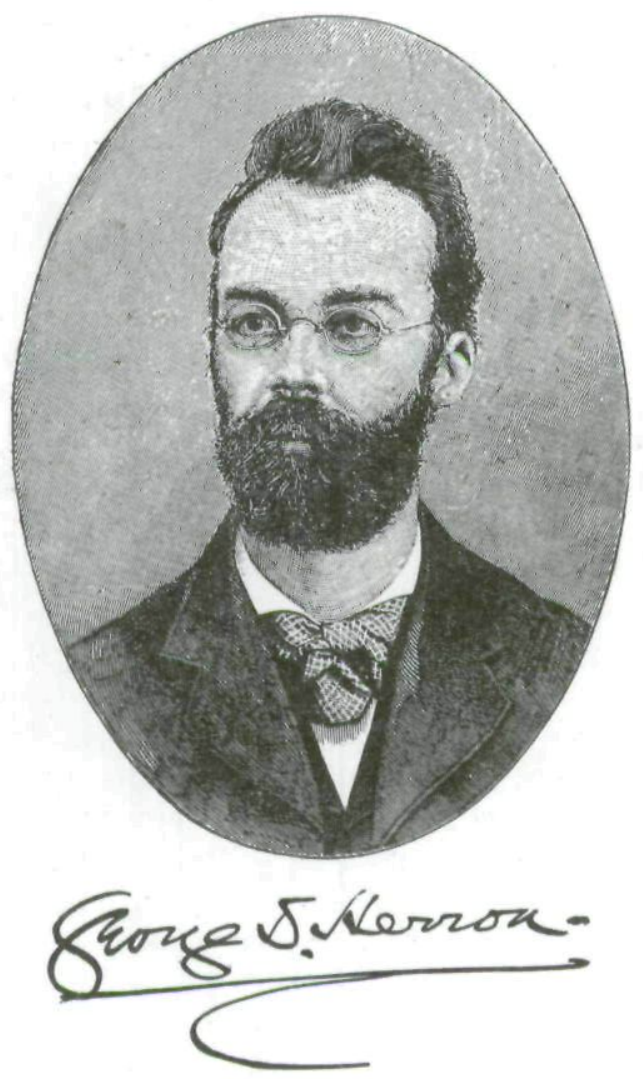

he convinced Mary V. Everhard, the red-haired daughter of the prominent physician who was also mayor of Ripon, to marry him; the couple soon moved to St. Paul, Minnesota, apparently to further Herron's plans for a career in literature and journalism. About 1883, however, he experienced a profound religious crisis. After the classic manner of generations of American Protestants,

I groped in that horror of darkness which settles upon a soul when it knows that there is no sound thing in it, and that it merits nothing but eternal death and endless night. The hopeless anguish of a lost life laid such hold of me that all the eternities seemed overwrought with speechless pain. I knew that nowhere had I an inch of standingground, save the mercy of God, and the least of all God's mercies 
seemed too great for me. Jonathan Edwards' Enfield sermon was, at that time, the only thing real enough to answer my experience. But out of this horrible pit I cried unto the Lord and he heard me, lifting me up and planting my feet upon the rock of his salvation.

He entered the Congregational ministry and had small churches in Dakota Territory, Atlanta, Georgia, Zanesville, Ohio, Lake Mills, Wisconsin, and Lake City, Minnesota. ${ }^{9}$

Meanwhile, Herron had been reading in wide if miscellaneous fashion several of the more reform-minded writers of both Europe and America. F.D. Maurice, Henry George and Mazzini were only a few of the men who became influential on Herron during the next decade. ${ }^{10}$ While minister of the Lake City church, in 1890, Herron gave the sermon that took him out of his obscurity and helped to make him famous throughout the Middle West. To audiences nurtured in the quasi-religious economics of Herbert Spencer and William Graham Sumner, he proclaimed that competition and inevitable progress were in fact not tied together. He insisted that if progress meant anything at all it meant moral progress, and that economic competition was always opposed to moral development.

In Herron's analysis, the problems of economic life boiled down to Cain's question, "Am I my brother's keeper?" Herron thought that men were in fact their brothers' keepers, but that capitalistic society assumed instead that selfishness and competition were more appropriate moral guidelines. God's answer to Cain's question was the cross: by giving men the example of Jesus atoning for their sins, God intended that men should follow this example by sacrificing themselves for others. Thus, the message of Jesus to every man, regardless of his financial circumstances, was to sacrifice himself by doing service to others. The man who did not do this was not living a moral or Christian life. This message had peculiar relevance to the life of the rich because they had so much more to sacrifice. If the wealthy men in America chose to follow Christ's example, then social problems would soon disappear. If they did not do so, then

\footnotetext{
${ }^{9}$ Herron, "Confession of Faith"; Handy, "George D. Herron .....," ch. 1.

${ }^{10}$ In addition to the books and articles cited in notes 6 and 7, see also Peter J. Frederick, "European Influences on the Awakening of the American Social Conscience, 1886-1904," (Ph.D. thesis, Univ. of Calif., Berkeley, 1966); Peter d'A. Jones, The Christian Socialist Revival, (Princeton, 1968); Daniel Day Williams, The Andover Liberals, (N.Y., 1941); and Robert Handy, "The Influence of Mazzini on the American Social Gospel," Journal of Religion, XXIX (1949).
} 
these men were immoral and ungodly. ${ }^{11}$

Herron quickly found himself in demand as a speaker and possible pastor at more important churches. His talk came to the attention of Charles Beardsley, who was chairman of a search committee of the Congregational Church of Burlington, lowa, and who wanted a young man to assist and eventually succeed the elderly William Salter, then the minister. With Beardsley, and his success in winning Herron for Burlington, historians have their first contemporary description of Herron and his peculiarly charismatic effect on people:

He was under thirty years of age, of gentle ways, in person slender, a little above the average height, but somewhat below the average in apparent strength and vigor, yet with a fine public address and a tongue touched with the fire of a very earnest purpose, and a spirit all aflame in its zeal for righteousness and consecration to the truth. $\mathrm{He}$ spoke, indeed, as one having authority-not in his own right, but in the sure utterance of principles from which there could be no appeal. ${ }^{12}$

At Burlington, Herron discovered that his superior would be William Salter, a crusty relic of lowa Band days, when idealistic eastern seminary graduates responded to the calls to evangelize the West. Salter had been in the middle of many battles: against Catholics, Universalists, slavery tolerators and rum sellers. He was vigorously "Old Light" in theology, and mildly pro-labor in some of his later writings. His biographer has found him "cautious, conservative and formal," and rather humorless, at least in his old age. ${ }^{13}$ Herron, being the more radical and visionary and at least equally stubborn, apparently did not get along especially well with Salter: the rebellions of one generation rarely appeal to the rebellious of other generations. Nevertheless, during his seventeen months at the church, Herron found that his sermons were well-received by the press, and that he was welcome in the town. He proved very energetic, spending much of his time organizing girls' sewing classes, evening classes for poor boys, ministerial retreats, and similar

11 "The Message of Jesus to Men of Wealth" is most conveniently found in George D. Herron, The Christian Society, (N.Y., 1969, c. 1894), ch. 4.

12 Hon. Charles Beardsley, "Professor Herron," Arena, XV, (1895), 784.

${ }^{13}$ Philip D. Jordan, William Salter: Western Torchbearer, (Oxford, Ohio, 1939), 217. For a useful "Who's Who" of these clergy, see T. O. Douglas, "Builders of A Commonwealth," an unpublished, thirteen volume compendium of 1-4 page sketches, in the Grinnell College archives. 
commonplace events in the life of any small town Protestant minister. Only his occasionally poor health seemed to mar this period in his life. ${ }^{14}$

While at Burlington, Herron met three people who were to play key roles in the next decade of his life. Mrs. E.D. Rand, a member of his congregation, was the wealthy widow of a Burlington lumberman. Aside from considerable wealth, she had an equivalent amount of intellectual and emotional independence, and her support of Herron in whatever he wished to do became one of the more remarkable aspects of Herron's story. Her daughter, Carrie, was quite attractive and just as attracted to Herron; the scandal surrounding her relationship to Herron, which began in Burlington, would follow her the rest of her life. George Augustus Gates, a theologically unorthodox Congregationalist minister, had been called to the presidency of lowa College in Grinnell in 1887. He first met Herron in 1892, when he asked the controversial new assistant minister to come to the college to speak for the traditional day of prayer for colleges, held on the last Thursday of January. Gates knew of Herron's writings-and had himself been in trouble for radical views-and wanted to meet and know more of the man who was making such a large impression in midwestern evangelical circles. Herron came and spoke, and it seemed to Gates that "he did set the souls of our young men and women on fire with a high and holy passion, such as is not common in experiences of that sort." At that time Gates did not plan to have Herron come permanently to the college, but Mrs. Rand soon made it possible. A long-time friend of the college, she had already mentioned the possibility of endowing a professorship, but Herron's name had never before been mentioned as a possible appointee. ${ }^{15}$

Gates consulted his faculty and they "unanimously" agreed that Herron should be offered a place on the faculty. Gates went to the board of trustees, and they concurred. Herron, and apparently Mrs.

${ }^{14}$ Beardsley, "Professor Herron," 784-96.

${ }^{15}$ George Augustus Gates, "Remarks on the Occasion of Dr. Herron's Resignation... Burlington, lowa, Burlington Hawkeye, May 16, 1893, 7; Isabel Smith Gates, The Life of George Augustus Gates, (Boston, 1915); John S. Nollen, Grinnell College, (lowa City, 1953); Prof. H. W. Norris, "Grinnell's Second President, George A. Gates," Grinnell and You, XIV, \#1, (October, 1934), 8-11; Laetitia Moon Conard, "The Development of Social Ideals in Grinnell, lowa," typed mss., Grinnell archives; Charles Noble, "Twenty-Five 'Years of Grinnell," typed mss., Grinnell archives (dealing with 1893-1918). 
Rand as well, refused at first, but the idea once planted seemed to grow almost of its own accord. By May 9, Gates could call a special meeting of the board of trustees, present a note from Mrs. Pand endowing the "E.D. Rand Chair of Applied Christianity," and "the note with every condition was heartily and with absolute unanimity, every member voting, accepted by the board of trustees. The note carried with it the call to Dr. Herron to accept the professorship and that vote, too, was with similar unanimity." Thus, Herron's radical theological and social views, well-known by 1893, were not impediments but attractions in the eyes of the school administration. He would come to further the old college traditions, and in Gates' eyes, “lowa college has always taught, teaches today, and, so God will, will always teach the actual applicability of the principles of Jesus Christ to every department of human life." On the face of it, no appointment could have been more welcome or appropriate to both Herron and the college. ${ }^{16}$

Few people at the time gave a thought to any other sort of motive. It seems likely, however, in view of what was soon common knowledge on the campus, that the appointment had at least as much to do with Herron's growing affection for Carrie Rand as it did with Christian sociology. The mutual devotion of Herron and the Rands was fully as strong as their devotion to a just society. Yet outwardly, Herron voiced what soon became a hallmark of his public self-analysis. He struck the pose of a man chosen by God as if by an influx of grace, rendered powerless by himself, and simply the instrument of divine will. He thus began, in his public letter of resignation to his church, the pattern of justification that made him at first irresistibly appealing to reformers, especially young and evangelical ones, and eventually the devil himself to a large segment of more conventional society. As he wrote:

I believe God has sent me with this message of a new redemption through His Son. I must go as I am sent. The chair of Christianity, endowed in memory of a noble and honored member of this church, opens the way for me to speak to the church at large. I do not resign one position to take another. I go to witness to the righteousness of society and the nation. I can do nothing else. I do not enter this open door because I expect to have an easier work. I go to toil as I never toiled. I go to suffer for the truth and name of Christ. ${ }^{17}$

\footnotetext{
${ }^{16}$ Gates, "Remarks."

${ }^{17}$ Herron's full letter of resignation is included in toto in Gates, "Remarks."
} 
Herron's appointment also brought the Rands and their money, time, and energy to the campus. Carrie soon became-while all of about nineteen years old-Instructor in Social and Physical Culture, and then "Principal for Women," while her mother apparently dominated the campus as a de facto dean and fund-raiser.

In lowa College, the Rands and Herron had found an ideal institution for furthering their views. Founded before the Civil War, as a direct result of evangelical and reform activity, it was a small college designed after the New England manner, located in a town recalling New England as much as was possible in central lowa. Strongly abolitionist, moralistic, and prohibitionist in the past, it had never had qualms about the correctness of Christian morality, or the right of Protestants to legislate their views into practice. If Herron could not survive and prosper here, he would have great trouble doing so anywhere. ${ }^{18}$

\section{III}

By the accounts of both his friends and his enemies, Herron's first impact on the campus was enormous. His classes were extremely popular, overflowing normal room-size so frequently that for a while they had to take place in the chapel. Far from being silenced by conservative townspeople or nervous trustees, Herron received adulation on all sides when he began his work, and even the assignment of what could be regarded as radical and left-wing material apparently produced no immediate strong opposition. The required reading for his courses, for example, included Richard Ely's Labor Movement in America and Social Aspects of Christianity, Washington Gladden's Tools and the Man and Applied Christianity, and Laurence Gronlund's The Co-operative Commonwealth. The college was so proud of its new "Department of Applied Christianity" that it even published a three-page leaflet describing the course and its reading list for the world to see. President Gates was certainly enthusiastic, and proudly informed Richard Ely of Herron's campus popularity and the many outside requests for his speeches. ${ }^{19}$

${ }^{18}$ See the references in note 15 , esp. Nollen, Grinnell College.

19 There are many relevant clippings preserved in the Grinnell College archives. See especially Box 1 , section A, which includes the pamphlet, "The Chair of Applied Christianity at lowa College," and material on Herron's popularity, radicalism, the list of guest speakers at the college, etc. See also the 
Unfortunately, the first flushes of success and enthusiasm both for Herron and his message were the highpoints of his lowa College career. In part, the opposition to Herron was the natural dislike of those more conservative and conventional than he. Led by men like history professor L. F. Parker on the faculty, and the aged trustee Col. John Meyer outside the faculty, the criticism of Herron for his radicalism slowly increased over the years until by the late 1890 s it became very nearly a majority position even within the ranks of the college. As early as 1894, however, Herron supporter Charles A. Young could be fearful of the possible results of Herron's manner of speaking. As he wrote to Richard Ely, Young felt "very much concerned about Herron" and that "those of us who love him ought to counsel him to be guarded in his statements." In fact, Herron seems to have been erratic in behavior, negligent toward his classes and his students, and extreme and violent in his expression of his opinions. That his case was not, pure and simple, a matter of academic freedom, is quite plain. President Gates, for example, retained the support of most men on both sides during the controversy, even though he was personally fond of Herron and agreed with many of his views. ${ }^{20}$

Herron's non-academic activities, indeed, soon all but preempted his time and energy. He joined enthusiastically into the work of the "Kingdom Movement" as soon as he arrived on the campus, and through it achieved much of his influence both over Gates and on Congregationalism. The movement had begun at the 1892 retreat called by President Gates, in an attempt to give formal expression to some of the reform impulses within Congregationalism. Through its journal, The Kingdom, with Gates as editor and Herron as associate editor, it soon was influencing men in many other Protestant

scrapbook of history professor L. F. Parker, pp. 34-89, 97-99, compiled by a Herron enemy on the faculty; Dieterich, "Patterns of Dissent," 40-44; and Gates to Richard Ely, January 31, 1894, Ely Papers, State Historical Society of Wisconsin (SHSW), as quoted in Dieterich.

${ }^{20} \mathrm{See}$ especially the many critical editorials and letters printed in newspapers in the Herron Papers, Grinnell College; these include John Meyer's "Herronism Exposed," and other lumbering critiques, File M, Box 1, and L. F. Parker's scrapbook; Charles A. Young to Richard Ely, September 18, 1894, Ely Papers, WSHS, as quoted in Dieterich, "Patterns of Dissent, 118-119; . Dieterich, "Radical on the Campus...." See also the Clínton Douglas material, File KL, Box 1, and the F. I. Herriott letter, File PQ, Box 1, and Gates answer, Box 2. 
denominations as well. Reformers as well known as Robert A. Woods, Washington Gladden and John Bascom were for a while public supporters of the movement, as were those like Charles Noble and Josiah Strong, who later opposed Herron. As Noble has described the early days:

We met morning and afternoon in the little tower room of Goodnow Hall; listened to chapters of forthcoming books by $\mathrm{Dr}$. Strong in the morning and Herron in the afternoon, discussing the topics freely, and having a very pleasant and profitable time together. The next year Herron received the appointment to the chair of Applied Christianity.... This "Retreat or Conference" grew in the immediately following years into the "School of the Kingdom." A gathering of a considerable company of really able and distinguished men, who discussed the application of the teachings of Jesus to social and political problems.

Herron's growing extremism, and Gates' open admiration for him, soon splintered the movement, and like Herron's own teaching career, it peaked at its beginning, and then petered out as a force largely because many original supporters could not follow Herron's lead. As Noble wrote sadly:

The movement was wrecked by the extreme socialistic tone which began to characterize Herron's utterances and to some extent those of President Gates. I remember Professor Parker taking me aside one of those days and saying: "it is time to line up one side or the other, for Gates is beginning to talk like Herron," by an utterly needless antagonism to the churches, a refusal to recognize the extent to which the church is already applying the lessons of gospel living to our community life, and finally by the moral catastrophe of Herron's life. Wrecked as a specific movement it left an influence which can never die. $^{21}$

Herron's ability to inspire adoration and dislike, so apparent in his "Kingdom" activities, came to national prominence with his other activities off campus. He was in great demand as a public speaker around the country; one episode, on June 13, 1894, which

${ }^{21}$ Charles Noble, "Twenty-Five Years of Grinnell"; Handy, "George D. Herron and the Kingdom Movement," and "George D. Herron and the Social Gospel ...." ; for a public Gates eulogy of Herron at this time see his article, "The Movement for the Kingdom," The Kingdom, VII (1894-5), 4. The Kingdom first appeared April 20,1894, as the seccessor of The Northwestern Congregationalist; it lasted five years, and in 1899 its subscriptions were taken over by The Social Gospel; in 1901 it, in turn, had its subscriptions taken over by The International Socialist Review, thus neatly encapsulating the shift from the religious to the political in social gospel thought which is crucial to the thesis of this article. 
received national publicity, occurred when a Herron speech so infuriated the Governor of Nebraska that he abandoned his prepared remarks and followed Herron with a denunciation that compared him to the anarchists, Lucy Parsons and Johann Most. The most useful trip for an analysis of Herron's public career and image was a lengthy stay Herron had on the West Coast in the spring of 1895, a trip subsequently written up with supporting documents by the sympathetic Arena magazine. As Adeline Knapp wrote in the introduction, Herron was invited by several San Francisco Bay area Congregational ministers who were anxious to hear him and thought their parishoners were also. When he arrived,

\begin{abstract}
the people thronged eagerly to listen to the professor from Grinnell. We have had many great teachers on this coast, but it is probable that not one of them ever produced so profound a sensation, or awakened so many people to a sense of the hopefulness, after all, of the effort to attain national righteousness, as Dr. Herron has done.
\end{abstract}

There was, predictably, great opposition as well, with the Rev. Mr. C. O. Brown, pastor of the First Congregational Church of San Francisco as the most vigorous critic. Brown followed immediately one Herron speech with a "virulent" attack, full of "rambling irrelevancies," and strayed so far from normal decorum that the chair had to call him to order. The next Sunday, and long thereafter, Brown continued his attack. "Calumny, misrepresentation, injustice, unfairness, are the methods by which the reverend gentleman has sought to bring discredit upon the new movement recently set forth ... which ... has been called 'Applied Christianity.' ",2 2

The most perceptive impression of Herron on this trip came from J. K. McLean, the President of the Congregationalist Pacific Theological Seminary in Oakland. He found that Herron had a

\footnotetext{
deep individuality. He is a man of the most exquisite sensitiveness. In this characteristic he closely approaches the feminine in type, [without being at all] effeminate. Quite the reverse. The two things are vastly different. His feminine quality does not detract at all from the fulness of his virility. It is only that the tissue of his character is extraordinarily fine-grained. Few men I have ever met, perhaps none, have so represented to my mind what I conceive to have been in this respect just named the quality of Jesus, an essential feminineness
}

${ }^{22}$ On the Nebraska affair, see the L. F. Parker scrapbook, p. 37, and the discussion in Nelson, "George D. Herron and the Socialist Clergy . . . , "85-6. On California, see the symposium, "Prof. George D. Herron: The Man and his Work in California," Arena, XIV, (1895), 110-128, quotes here from 110-111. 
joined with an equally developed masculinity. It is a rare and high conjunction of qualities.

Herron was constantly maligned and misrepresented, yet "from first to last he exhibited under this fire of detraction a perfect serenity of spirit and an absolute freedom from all asperity of speech or feeling."

In addition, McLean emphasized Herron's

spiritual susceptibility. Spiritual things are the most real to him of all things. He lives and moves and has his being in a spiritual atmosphere that is both dense and luminous. Above all those I have ever known he seems to me to come nearest to Moses' way, and to walk as seeing Him who is invisible. Professor Herron tells us that in his early life, when he was yet apprenticed to the printer's trade and earned his living at the compositor's case, he knew and had companionship with almost no human being. But God he knew and had companionship with in a way that was as real as any other reality of his life. And this experience has been a constant and increasing one from that day to this. The dread and solemn presence is ever about him ....

This is the chief key to the man's character and aim and work in life. He is possessed of an overpowering sense of God: God's will, God's righteousness, God's leading, God's comfort; and has an abiding joy in the Holy Ghost.... Whether man will heed or will forbear, Professor Herron so feels the hand of God upon him that he must speak out God's message to the world. ${ }^{23}$

As McLean's impressions make abundantly clear, Herron's own sense of his communion to God, by some alchemy of personality, could be sensed by others, and made a profound impression upon them, and added greatly to the impact of ideas that might otherwise not have proved so attractive. And, as the opposition of people like C. O. Brown indicated, when a person felt committed to other views and believed in their Godliness, Herron's air and attitude proved infuriating. Put into the more political terminology of the Progressive Era, the issue could be stated: was reform, even reform as radical as socialism, compatible with God's will, and perhaps even demanded by the ethics of Christ and his sacrifice? Or was the existing order inherently good, and ordained by God, and attempts at radical reform inherently blasphemy? Beneath Supreme Court decisions like Lochner v. N.Y., anti-trust efforts, the campaigns for gas-and-water socialism in the cities: wherever we look, the outwardly political and social issues of the day seem to have rhetoric echoing the controversies that followed Herron around the country.

23 “"Professor George D. Herron .... ,"Arena, XIV, (1895), 111-114. 
The Populists very quickly realized that they had a potential leader on their hands, whose religious and political views fitted quite well into the pattern of agrarian discontent in the 1890s. Over the course of several years, as Herron moved slowly left and became more and more controversial, Iowa Populists kept up a persistent pressure upon him to run for Congress or for Governor on the Populist ticket. Herron was devoted to the views of the party, but he was never inclined toward direct political action himself, and his poor health and growing marital problems would have made any sort of vigorous and long-term career difficult. He did, however, take care to make clear to the faithful his support of the religious socialism inherent in Populist planks. He thought the movement "permeated by a profound religious feeling," and hoped to see "out of these Western States the greatest religious movement since the Reformation. It will be a revival of faith in Christ closely akin to Primitive Christianity." 24

Far from finding any meaningful contrast between populism and progressivism, Herron moved almost imperceptibly into organizations and campaigns that marked the rise of both movements. Either as a member or frequent speaker, Herron associated himself with the National Christian Citizenship League, the Union Reform League, and most important, in 1899, the National Social Reform Union. Through these groups he became well-known to most active progressives as well as populists. Newspaper accounts of the Buffalo convention of the National Social Reform Union, June 28-July 4, listed his name second only to its leader, Governor Hazen Pingree of Michigan. The names following Herron's were an honor roll of political and social progressives that most accounts never really associate with religious movements at all: Richard Ely, Henry Demarest Lloyd, Eugene Debs, Graham Taylor, John P. Altgeld, Jane Addams, John Commons, etc. Herron's speech at Buffalo, indeed, was a criticism of McKinley's Phillipine policy.

Another delegate to the Convention, Samuel M: "Golden Rule" Jones, the famous "Golden Rule Mayor" of Toledo, had been a long-time adinirer of Herron's. He had tried to run his factory after

\footnotetext{
${ }^{24}$ See the material in file " $\mathrm{S}$ " of Box 1, Herron Papers; "Dr. Herron on the Bryan Movement," The Kingdom, IX (1896-7), 798; Handy, "George D. Herron and the Social Gospel....," 51-5; Dieterich, "Patterns of Dissent...," 124 ff.
} 
Herron's principles, and a few weeks earlier in June, 1899, had been graduation speaker at lowa College. Herron immediately repaid the debt by campaigning vigorously for Jones during his unsuccessful third-party try for the governorship of Ohio, a first active effort in democratic political campaigning. In 1900 Herron continued his activity by campaigning for Eugene Debs, and occasionally thereafter participating in Socialist candidacies. He thus managed to be a Populist, a Progressive and a Socialist, and was accepted readily as one of their own by politically active members of these movements, without much changing or moderating his views on any particular subject. The barriers historians traditionally erect between these three movements, if Herron is at all typical, are a great deal higher than the facts seem to warrant. ${ }^{25}$

IV

As his public career peaked, Herron's private life slowly disintegrated, if examined in the light of the moral values of his time. Even before he came to Grinnell, rumors had circulated in Burlington that his relations to the Rand family were rather closer than was wholly appropriate. He and they had a mutual influence on one another. Mrs. Rand apparently persuaded Herron to accept the call to lowa College; she put up the money for his salary, and she all but took over aspects of college life when they arrived. During the middle 1890s, she also put up the money for a Rand Gymnasium, finally dedicated in 1897.

The students in those more "innocent" days apparently did not suspect that anything out of the ordinary was happening, but the relationship between the two families could hardly have escaped the eyes and tongues of a small college town. All the Herron children called Carrie "Aunt Carrie," and one of them was actually named Caroline Rand Herron. The Rand house was directly across the street from the campus, and Herron had a room reserved there for him so that he could rest between classes; his own home was just down the

${ }^{25}$ Handy, "George D. Herron and the Social Gospel .... ," 115-6; Dieterich, "Patterns of Dissent . . . .," $127 \mathrm{ff}$.; file " $\mathrm{R}$ " in Box 1, Herron Papers, has the relevant newspaper material on the Buffalo Convention; for his Philippine views, see Herron's "American Imperialism," The Social Forum, Vol. I, \#1, (1899), 13-18; Harvey S. Ford, "The Life and Times of Golden Rule Jones," (Ph.D. thesis, University of Michigan, 1953), ch. 4, especially p. 49 . 
street, a block away. By 1897 and 1898, most faculty were aware of this, and at least a few were repeating the off-hand remark of one of Herron's children, that "We don't have meat for dinner any more because Papa has his dinner at Aunt Carrie's." Even when the Rands and Herron traveled on European cruises together, however, the students apparently suspected that nothing unusual was going on. The last of these trips, it is believed, proved decisive for Herron and Carrie because when they returned he asked his wife for a divorce. On March 22, 1901, Herron received his divorce, and two months later he married Carrie in a modern "socialist" marriage ceremony that shocked as many people as the divorce itself. ${ }^{26}$

In terms of Herrons's career and influence, the scandal of his private life was largely anti-climax. Herron had been sick, and his lengthy trips had been in part quite legitimate attempts to restore his health. His health had never been good, even as a small boy, and the strain of his public speaking was too much for him. But the combination of travel for speaking, and then the travel for health, meant that his duties at the college became increasingly neglected for longer and longer periods of time. Advanced students, and sometimes even President Gates, substituted for Herron in class, but it was inevitable that criticism would arise about the highest-paid member of the faculty not performing even the minimal tasks expected of others. Enrollment in Herron's classes dwindled rapidly after the first extraordinarily successful year, and after 1896 he was lucky to have twenty students register to study with him. At the same time, public controversy about his political views became more intense, and the consequent pressure on the Board of Trustees rose. Contributions from non-Rand sources diminished, and the inevitable alumni threats of financial retaliation became more repetitious. Herron was apparently the topic of several meetings of the board, beginning with the June, 1896, meeting, and continuing until his retirement, and the subsequent resignation of President Gates. ${ }^{2}$ ?

${ }^{26}$ Fanny Phelps Johnson, "Some Remarks on Caroline Rand and Clara Millerd," typescript, 1939, in Grinnell College Archives. File YZ, Box 1, Herron Papers, has many examples of editorial comment on the divorce and remarriage, with dates and the description of the marriage ceremony. See esp. the Chicago Record-Herald, May 27, 1901.

${ }^{27}$ Many newspaper clippings in the Herron Papers chronicle his illnesses, his dwindling campus popularity, and the public pronouncements of the Board. See esp. the L. F. Parker scrapbook, pp. 41, 48, 49, esp. the Grinnell Herald for November 17, 1899. 
The general tone of the controversy within Grinnell, despite all the nasty things that were being said about Herron elsewhere, seems to have been a model of how a college community should handle a temperamental faculty member. Whether Herron would have been treated less fairly had not the Rand money and President Gates' influence been on his side is certainly arguable, if not especially relevant; Herron would not have been in academia at all, let alone at Grinnell, had not Gates and Mrs. Rand pleaded with him to come. The surviving Herron Papers are almost totally lacking in private correspondence, but several significant letters do survive on this issue that are worth quoting in detail as official statements on why Herron was in trouble, and how he reacted to criticism. Messrs. J. M. Chamberlain and R. M. Haines, representing the Board of Trustees, wrote to Herron at Geneva, Switzerland, February 23, 1897, outlining the various complaints that had been made against him, and summarizing them as follows:

1)The department has gained but slight sympathy from the faculty as a whole; 2)There has been a decline in the interest of the students in its teachings; 3 )there is a settled indifference or aversion to the Chair and its work in the Christian community about the college; 4)there is a want of sympathy with, or hostility to, the instruction of the Chair, without or within the college, on the part of the pastors of the congregational churches of lowa which are the special constituency of the college, and who anticipated the work and the results of the Chair with much enthusiasm; 5) there is very noticeable alienation of mature business and professional men, and such intelligent men and women as our colleges are wont to look to for endowments, and their financial and moral support in their community; 6)there is a widely prevalent feeling wherever the teachings of the Chair are known, that they are intemperate and unsafe, and this feeling is manifested also in the religious and secular press; 7)we think the same feelings are entertained by the ablest teachers in our higher institutions of learning, public and private, and by educational writers.

In their view, Herron should exercise more discretion in his actions and express himself more soberly when he spoke in public. The entire letter, and an accompanying note from Chamberlain alone, seem quite friendly and reasonable in tone. ${ }^{2} 8$

Herron's reply was characteristic of the man when engaged in his private affairs. By all accounts, Herron off the platform was a charming man, engaging and likeable, and without the stridency that

${ }^{28}$ J. M. Chamberlain and R. M. Haines to George D. Herron, February 23, 1897, Herron Papers, Grinnell College. 
increasingly marked his public discourse. He could be humble and courteous when he wanted to be, and simply ignore several of the criticisms if he felt so inclined.

Now let me say at once, and say frankly, that I believe the trustees have here a perfectly just ground for complaint and cause for anxiety. In looking over my work of the past three years I myself had come to see, long before your letter came, that there had been in that work too much of the element of condemnation, and too little of real consideration for the opinions and feelings of those who saw things differently. This fault arose, not so much from any conscious impatience witt; other men and views, as with a failure to put myself in their place. I feel that I have not taken the trouble and patience to make myself understood. I think there are many who now think themselves antagonistic to my teachings who could be won, at least to friendliness of attitude, if they better understood what I am trying to do. That they do not is quite as much my fault as theirs. The ground of complaint which the trustees have in this particular I freely acknowledge, and wish to assure them that I shall do all in my power to recover what has been in this way lost.

He thus blithely passed over the whole issue of his lack of attention to his classes, or the fact that if he were properly understood the controversy would be quite great enough for any college. Instead, he remarked that any advance in teaching would produce "a greater or less commotion and dispute," and that the new Christianity was quite as disturbing to many people as Darwinian evolution had been. He also claimed, typically enough with no specific examples, that he had been criticized for saying many things that he had in fact never said. Herron, in this letter, had an excellent opportunity for clarifying his views and settling a number of misunderstandings, but he did not take the opportunity, and never did. In this, surely, he is culpable. He then ended with the wholly remarkable, and absolutely untrue sentence: "You will never find me posing as a martyr, whatever you do." 29 In fact, no role appealed to him quite so much, or reminded him so much of Christ, as that of martyr, offering himself for sacrifice for the social sins of the world.

Both Gates and Mrs. Rand vigorously resisted any attempts to fire Herron, but they were slowly worn down. Mrs. Rand issued a detailed statement of how much money she had contributed to Herron and the college, and challenged anyone to match it. By 1899, however, Herron had had enough, and it seems reasonable to

\footnotetext{
${ }^{29}$ Herron to J. M. Chamberlain and R. M. Haines, May 25, 1897, Herron Papers, Grinnell College.
} 
suppose that his impending divorce and remarriage, which were not as yet known to his critics, contributed at least as much to his decision as the criticism of his religion and politics. He finally resigned, in a letter dated October 13, 1899. Shortly thereafter, the scandal of his divorce soon made his earlier controversies seem mild by comparison. ${ }^{30}$

Judged from a distance, Herron changed during the 1890s in a radical way. He came from theologically conservative evangelical Congregationalism, a hero to many reform-oriented clergy and men active in political and economic life, and became a left-wing socialist, despised by most of his former friends, expelled from his church, and denounced throughout the land as a dangerous radical and believer and practicer of free love. Seen close up, however, Herron changed very little. Most of his later ideas are implicit in his earliest publications. Not his ideas, but public understanding and acceptance of them, did most of the changing.

In Herron's mind, heaven and earth, God and man, were not separate but unified. God was human and man was divine. Social and economic problems, properly understood, were thus really religious problems, and religious problems always had their social and economic implications. Christianity and sociology were thus synonymous. Within this framework, the figure of Christ was central. In his character, he was the summation of the best God thought man could become, the incarnation of God's will. The reformer, conscious of discrepancy between what he sees in society around him and what he finds when he studies Christ and religious texts, tries to make his society become more in tune with his understanding of Christ's nature. "The search for some complete law of justice between man and man, the search for remedies for social ills, is essentially a search after the Christ." ${ }^{31}$

${ }^{30}$ File "PQ" deals with the trustees' actions of 1899, and has the details of Mrs. Rand's offer; she subsequently withdrew her threat to take her money back, and gave it unrestricted to the college. File " $T$ " deals with the resignation. For more detail, Dieterich, "Radical on the Campus," is an able analysis.

${ }^{31}$ George D. Herron, The New Redemption, (N.Y., 1893), 48; The Larger Christ, (N.Y.,1891), 18-22. 
Christ's chief message for men was that selfishness was evil and self-sacrifice central to any kind of religious life. Selfishness was a subject Herron returned to again and again; he saw it as a "separation from God and humanity. It is the origin of evil. The man is a devil who is sufficient unto himself in whatsoever he is or does." The only way for a Christian to fight selfishness both in himself and in society was to practice, at all times, self-sacrifice in imitation of Christ on the cross. "The most glorious career that love can conceive for its object is one of complete sacrifice in the service of the common life," he wrote. He then went on to insist that "no life is to be thought of as Christian that is not made sacred for the social service, and thus fully sacrificed in bearing away the sins of the world." Even detachment from self-interest would not be enough, for Christ's example showed that society would take its revenge, and might well demand martyrdom from any man who was too insistent on changing its sinful ways. "For, I frankly acknowledge and declare, no man can practise this gospel without suffering loss and persecution through conflict with the opinions and customs of the world." ${ }_{32}$

Unlike most Christian reformers, Herron apparently could not stop at simply trying to follow Christ's example. Instead, he seemed to identify himself so closely with Christ that, mutatis mutandis, his descriptions of Christ become very much like self-portraits, and his message to his listeners a demand that they follow George Herron as he takes upon his head a crown of thorns and suffers martyrdom for the sins of the world. In view of the events of Herron's own biography, for example, the following description is striking:

While no one ever so hungered for human sympathy as Jesus, no one
was so misunderstood-even down to the present day-by his own
disciples, his own church. No one ever so yearned to express his
affection; so longed and tried to explain himself and his mission. Yet
his own mother understood him not; his brethren did not believe in
him; every human companion seems to have been a broken reed
piercing him to the heart; his disciples, until the day of his death,
were loyal mainly from selfish motives; a disciple whose feet he had
washed betrayed him; the sturdiest of them all denied him; they all
forsook him and fled; the multitudes who had felt the healing power
of his compassion, the authority of his words, the divineness of his
being, and witnessed the miraculous and beneficent demonstrations of

${ }^{32}$ The Larger Christ, 77-9; Social Meanings of Religious Experiences, (N.Y., 1969, c. 1896), 37, 43; New Redemption, 138. 
his power, shouted for his crucifixion; his own nation rejected him; his own religion crucified him; and thus, he presented himself, the willing victim of our sins, to be rent in soul, mangled in flesh, broken in heart, that he might show us the Father, show us ourselves, and lead us back to our Father's house. ${ }^{33}$

No one understood Herron; he was full of love for everyone; his friends were betraying him, and his church would soon reject him officially; his students left his classes; his country soon so pilloried him in its press that he felt he had to emigrate-the whole pattern of events is too striking to pass over.

Indeed, whether by Herron's own suggestion or not, many of his disciples noted and commented on his striking similarity to Christ. His personality did in fact give people the impression that he was divinely inspired. To The Reverend Mr. William T. Brown, for example, Herron and Jesus seemed to have many qualities in common. Selfless love and devotion to social welfare dominated both. Neither was institutional; both were divinely inspired individuals. Herron's life, Brown wrote, "has been one long crucifixion," and Herron a selfless saint. Even his divorce and remarriage did not dim his qualities in Mr. Brown's eyes. Indeed, in his suffering for his behavior, Herron's heroic silence and noble mien "exhibited qualities of character which are nothing less than divine." ${ }^{\prime 4}$

Whatever his inspiration, Herron's message became clearer as the 1890s wore on: capitalism is organized selfishness, and its only cure is state socialism. Herron had long condemned competition and the profit motive in general terms, but by the time of Between Caesar and Jesus, a 1899 book that included eight lectures given in Chicago in the fall of 1898, no one could mistake the political consequences of his views. Where earlier he had exhorted businessmen to lead Christian business lives, he now flatly proclaimed that this would be a contradiction in terms, "for business is now intrinsically evil, whatever good may come out of it." Throughout the course of history, "private ownership of natural resources rests upon fraud, violence and force." Like Henry George, he insisted that "private ownership is social trusteeship, that is all: it is not private ownership in any real or right sense," and it therefore followed "that the public ownership of the sources and means of production is the sole answer

${ }^{33}$ The Larger Christ, 59-60.

${ }^{34}$ Rev. William T. Brown, "George D. Herron: The Tragedy of Conscience," Arena, XXV, (1901), 471-85. 
to the social question, and the sole basis of spiritual liberty." Thus, if a man was to be able to express his best qualities of character, and be able to grow to become the ethical being that Christ wished him to be, "the resources upon which the people in common depend must by the people in common be owned and administered." Only if the ownership of the earth is held in common can liberty and individuality take proper root. "Liberty as a human fact means communism in natural resources, democracy in production, equality in use, private property in consumption, and the responsibility of each for all and of all for each." To a generation that seemed to believe that money was a sign of God's blessing, he said flatly that there could be "no such thing as a rich Christian." 3 s

Yet even though Herron became more specific in using terms like "communism" and "socialism," and by his attendance at conventions and support of candidates and platforms identified himself with many progressive and socialist measures, one seeks through his own books in vain for anything specific. He did not understand politics or economics, and he had no interest in studying either. What he had to say was clearly derivative exhortation from the previous generation of British, Italian and American reformers whenever it touched specifics. It is at this point that Herron has much to teach students who wish to understand the true dynamics of the progressive mind. He, like so many more obviously political progressives, was really an evangelist at heart, wanting an inner conversion in his audience. Herron once argued that "the spiritual alone is the real and eternal," and this thought, probably bootlegged in from his occasional reading in Hegel, sets his whole reform outlook into perspective. If he could persuade a man to change his heart and devote his life to altruism, if he could do this for a whole society, then the Kingdom of Heaven would reign on earth. It remained for Walter Rauschenbusch to give this thought its fullest expression, but it is implicit in all of Herron's writings. The nitty-gritty of politics thus became slightly "unreal," since only the ideal, and the conscience, were important. This attitude goes to the heart of the problem of why progressives, by and large, were so rhetorical, and so ineffectual. They seemed to always have a tendency to believe that personal regeneration would achieve social

\footnotetext{
${ }^{35}$ George D. Herron, Between Caesar and Jesus, (N.Y., 1899), 26, 95-100; L. F. Parker Scrapbook, 58, Grinnell College Archives.
} 
regeneration, and thus that specific programs were merely waystations. A campaign for good men in office, by means of the initiative, referendum and recall, for example, is but a secular expression of this essentially religious and "idealistic" frame of mind. ${ }^{36}$

Thus, Herron's reputation for radicalism was really superficial analysis. His discontent with present conditions was very great, and he thought they ought to be entirely changed, but he really had no program in a meaningful political sense-certainly nothing resembling the very real grappling with issues that we find in a non "progressive" socialist like Eugene Debs, and that was so characteristic of the New Deal of the 1930s.

We need no program of action save the words of our Lord, sending us, as he was sent by the Father, to please not ourselves, but give our lives as bread and meat to a hungry world .... The complete reformation of the world, the reconstruction of society, the saving of the Christless multitudes, will come through the acceptance of the mastership of Jesus on the part of the church that bears his name. There are no social problems in fact. They exist only in the imagination of unbelief. ${ }^{37}$

\section{VI}

Several aspects of Herron's career seem remarkably striking in the light of the best work in recent religious psychology. The work of Erik Erikson in particular, while on specific topics often far removed from Herron's life and historical period, sheds light on some of Herron's less explicable behavior. ${ }^{38}$ Given the scanty nature

${ }^{36}$ Herron, The Call of the Cross, 26. All of Rauschenbusch's books, and Sharpe, Walter Raushenbusch, contribute to these conclusions. For an extended analysis of this frame of mind in a political frame of reference, see Robert M. Crunden, A Hero In Spite of Himself, a study of Toledo, Ohio under Samuel Jones and Brand Whitlock.

${ }^{37}$ A Plea for the Gospel, (N.Y., 1892), 82, 102.

${ }^{38}$ The most useful of Erikson's books for my discussion has been Young Man Luther, (N.Y., 1958). Other works of his which have contributed to my understanding of the subject are Childhood and Society, (second edition, revised, N.Y., 1963), Insight and Responsibility, (N.Y., 1964), "On the Nature of Psycho-Historical Evidence: In Search of Gandhi," Daedalus, XCVII, (Summer, 1968), 695-730, and Gandhi's Truth, (N.Y., 1969). On Erikson, Robert Coles, Erik H. Erikson: The Growth of His Work, (Boston, 1970) is an adulatory discussion of Erikson's printed work, with some biographical detail, but poor in organization and with no sense of intellectual historical context at all. The section on Erikson in Henry W. Maier, Three Theories of Child Development, (N.Y., 1965), is accurate, concise and trenchant, but again without historical context. Historians can consult with profit also Bruce 
of genuine contemporary documentation of Herron's early years, insights of this nature can only be labeled speculative, but they are nevertheless highly suggestive about why Herron acted as he did, why he was so spectacularly successful for a short time, and why he fell from grace with such suddenness.

The most obvious psychological characteristic of Herron's early years is the loneliness and sickliness that caused a constant fear of death in both himself and in his parents, and the unity of family influence on the formation of an intensely religious superego. "I may have been converted before I was born," Herron wrote, before detailing the religious history of his family. If Erikson's work on the basic trust/mistrust of earliest childhood is taken seriously even on a relatively non-technical level, it is not hard to see how the fear of death and the abnormal intensity of religious faith in the home could lead to an abnormal dependence on God. Young George was quite literally in such health that "only God could save him," and thus both normal Oedipal feelings obtained through his mother, and the normal urge toward a masculine place in society obtained through his father, were channelled with extraordinary force toward a totally dependent faith in God that could not be questioned.

Throughout his life, even Herron's enemies could remark his social charm in small, personal relationships, as well as the stridently provocative manner of his public addresses to impersonal audiences. The key to this combination seems to lie in Herron's persistent need for dependence on a feminine figure of serenity and competence. This need obviously began in his personality in the sickly child's dependence on his self-sacrificing and deeply religious mother, and Herron's rather desperate years as a poor and apparently orphaned printer's apprentice only accentuated his need. In his late teens, as we have seen, he went through an anguished conversion experience of the classic Puritan kind, complete with reading in Jonathan Edwards. Soon after, he met and married his first wife, she helped him to settle down, and with her support he found, in Erikson's terms, both intimacy and identity. His career as a minister was under

Mazlish, "Clio on the Couch," Encounter, XXXI, \#3, (September, 1968), 46-54; Bruce Mazlish, ed., Psychoanalysis and History, (Englewood Cliffs, 1963), especially the articles by the editor and Bernard Brodie; Fred I. Greenstein, Personality and Politics, (Chicago, 1969), and David Rapaport, "A Historical Survey of Psychoanalytic Ego Psychology," Psychological Issues, I,i,
(1959). 
way. ${ }^{39}$

Little information about the first Mrs. Herron has survived, but what has indicates that Herron was perhaps abnormally dependent on her for emotional support and the affirmation of his values. Fanny Johnson's memoir of the lowa College years contains this illuminating passage:

But for all his idealism he was a vain and selfish man who depended for his sense of well-being upon the adulation of some woman or women. When they first came to Grinnell it was understood that he could not lecture successfully if Mrs. Herron were not in the audience, and she was required to sit with uncovered head, that her beautiful red hair might be for him a beacon and an inspiration.

At virtually the same time, Herron could dedicate one of his books to his wife, "who has been to me a living conscience." Is that to be taken as a statement of simple devotion to Mrs. Herron's values, as an ironic way of saying she was a nag, or an expression of latent guilt about the slowly ripening relationship to the Rand family? At the very least, however, the fusion of "conscience" and dependence in his wife was clear in Herron in the early 1890 s. $^{40}$

Even in the Burlington years, however, Mrs. Herron was losing out to the strong maternal figure who dominated the next decade of Herron's life. It seems clear from the few facts that survive that Mrs. Rand's money, and her influence were decisive in changing Herron's mind about moving to lowa College, and that those same influences led to his resignation from the college. She, too, may well have been the figure who energized Herron, who had faith in his ability and possible great future, and who gave him the support he so desperately needed. Literally a poor boy come from nowhere he was, with her help, suddenly without financial worry and a possible William Jennings Bryan of American religion even before Bryan's brilliant arrival in 1896. As Erikson has written,

it is clear that organized religiosity, in circumstances where faith in a world order is monopolized by religion, is the institution which tries to give dogmatic permanence to a reaffirmation of that basic

${ }^{39}$ The chief document for this analysis, and the most important one for any study of Herron's career on any level, is "The Confession of Faith," from the Burlington Hawkeye, December 31, 1891', 2, 4.

${ }^{40}$ Fanny Phelps Johnson, "Some Remarks ..... ," Grinnell Archives; A Plea For the Gospel, (N.Y., 1892), has the dedication. It is perhaps worth noting that the 1895 edition of The Call of the Cross, (N.Y., 1892), was dedicated to Carrie Rand. 
trust-and a renewed victory over that basic mistrust-with which each human being emerges from early infancy. ${ }^{41}$

With first Mrs. Rand, and then beautiful daughter Carrie to believe in him and to support him emotionally and financially, Herron could conquer his students and then the country; and for a while he very nearly did.

Unfortunately for his private life and his career, Herron did not have the inner stability to control either his psychological dependencies or their resultant theological manifestations in socially acceptable ways. His subsequent career resembles nothing so much as the antinomian crisis of early years in Massachusetts Bay, and the career of Anne Hutchinson. Just as Anne's physiological and psychological problems led to too strong an attachment for John Cotton, resultant extremes of doctrine, a trial and expulsion from the church, so Herron's abnormal dependence on Mrs. Rand led him to similar extremes of popularity and exile. All comparisons of this sort can be carried too far, but there can be no doubt that Herron translated his inner insecurities into affirmations that he himself was will-less, and that God spoke through him. ${ }^{42}$

Again and again, Herron insisted on his will-lessness, and his being clay in the hands of the potter. In his autobiographical confession, he talked of his vocation: "As to my reasons for preaching the gospel, there is but one: I could not help it. I dared not do else." A year and a half later, in his resignation letter to his Burlington church, he repeated the theme:

The circumstances and outlook attending this call [to the Rand Chair at lowa College] leave me no choice but to enter this new work as a door of urgent opportunity opened by the Son of Man, in whose name I preach, by whose strength I live. I should not dare to refuse the call....

I believe God has sent me with this message of a new redemption through His Son. I must go as I am sent .... I have no choice in the matter. I can do nothing else.

By the time these sentiments, which are obviously psychological in origin, reach Herron's published books and sermons, the result is antinomianism whether so-called or not. Herron is but the helpless medium of expression for the will of God:

${ }^{41}$ Erikson, Young Man Luther, 257.

${ }^{42}$ For a stimulating psychological discussion of Anne Hutchinson's antinomianism, see Emery Battis, Saints and Sectaries, (Chapel Hill, 1962). 
To fulfill the divine obligation the revelation of God in Christ lays upon us, we must give ourselves to God. We must let God have his way with us; speak his thoughts in us; do his deeds through us; let God's Word dwell in our flesh, so that everything we do, in work or play, in public or private, shall be in communion with God..$^{43}$

As the puritans, led by John Winthrop, fully realized, such doctrines could easily lead to social anarchy. A person who believed that God was speaking directly to him or her, without the medium of church or minister, became immune to counsel and law. Why should Anne Hutchinson listen to John Winthrop when she could listen to God? Why should George Herron listen to critical newspapers, conservative clergy, or aged school trustees when God was using him as His instrument, and Mrs. Rand provided all the necessary money, moral support, and even a beautiful daughter? Why, indeed? After the now almost classic Eriksonian pattern, Herron's psychological and ministerial roles converged in a reform ideology that made him totally righteous, and his enemies totally wicked. His critics were perfectly right: Herron was indeed arrogant and abusive in his criticisms of existing churches and social systems. He had divided the sheep from the goats and found opposition psychologically intolerable. ${ }^{4} 4$

We do not really know why Herron changed his mind so abruptly in 1899, from fighting his opponents strongly to submitting his resignation with an air of sweetness which even his enemies approved. The scandal of the divorce and remarriage had not occurred, and only Herron's insistence made it occur at all; Mrs. Herron never threatened to expose the maternal menage à trois, and apparently did not want an open break. But it seems likely, as Robert Handy has suggested, that Herron planned a wider role for himself, and a greater audience for his words. In short, lowa College was too small to contain a man who was privy to the words of God. Herron spoke often and publicly until the scandal made his life in America intolerable, and he may well have planned to lead a progressive-populist-socialist movement along the lines of the Buffalo Convention, the platforms of friends like Golden Rule Jones, and socialists like Eugene Debs and Morris Hillquit. But instead of

${ }^{43}$ Herron, "Confession of Faith"; the resignation letter appears in its entirety in George A. Gates, "Remarks.... Burlington, lowa," Burlington Hawkeye, May 16, 1893, 7; The Call of the Cross, 105-6.

${ }^{44}$ See especially Erikson, Young Man Luther, 41, Childhood and Society, 261-3; and Identity: Youth and Crisis, 142-231. 
fame he found infamy, was expelled from his church, and found the newspaper publicity so hounding that he fled permanently to Italy. There, the Rand money, which had already made him very nearly the highest-paid critic of capitalistic influence on American colleges resident on any campus, now made him the most luxuriously comfortable left-wing socialist in all Europe. One wonders if he lacked all sense of irony or humor. ${ }^{45}$

\section{VII}

In looking over Herron's career in the 1890s, then, we have an important "progressive" figure. He was, as Robert Handy has pointed out, a leader of the Kingdon Movement, perhaps the most important organized force within the social gospel; and he was, as Phyllis Nelson has shown, the most important of the socialist clergy. He was also attractive enough to the Populists to make him several times their indicated choice for political office, even though he refused to run. He was closely identified with Progressives, and played an important role in the gubernatorial campaign of Golden Rule Jones of Ohio, and in the Buffalo convention of progressive leaders. He spoke often at settlement houses, and was regarded as a reform leader by Jane Addams, Robert Woods, and others. Clearly, he was an important figure in many progressive movements in his time, yet he came nowhere near qualifying for membership in Richard Hofstadter's status resentful middle class, or indeed any class. He had been desperately poor, became a preacher, and married great wealth and scandal. The possession of money did not seem to alter his views at all. Clearly, older historical categorizations are inadequate to understanding his career and importance.

What I argue may seem obvious in Herron's case, but has been neglected in its larger political context. My thesis is that Herron's career is unified by his religious outlook, and that this outlook is what made him see wealth and industrialization and poverty with such critical eyes. In effect, he was an overt example of what was covert in progressives and populists like Bryan, Jones, Ely, and the

${ }^{45}$ The dissertations by Briggs, Handy, Nelson and Dieterich all examine the resignation; Nelson deals most fully with Herron's socialism, and Dieterich with the context of his European career. In addition, Fanny Johnson, "Some Remarks....," describes briefly the Italian villa life, as does Mabel Dodge Luhan, European Experiences, "Intimate Memories," II, (N.Y., 1935), 243-6, although with characteristic inaccuracy she calls him "John D." Herron. 
others with whom he associated, or whose views resembled his. I am suggesting that populism and progressivism, properly understood, are both essentially religious at their bases; that men grew up in Protestant homes, adopted religious and moralistic attitudes toward right and wrong, and then applied these attitudes to the wrongs of society as they saw them. If I am correct, this would explain the persistent reform tendency to preach and moralize during the period, and to settle for laws that seemed to separate the sheep from the goats, but that in fact did not really touch the real bases of power in political and economic structures. Political life in the period became a great morality play, as mankind was crucified on crosses of gold, bull moose stood at Armageddon and battled for the Lord, and God chose America to make the world safe for democracy. Social class structure or economic affluence do not explain these things nearly so well as religion. Many of the men and women involved were not even, strictly speaking, religious; but they were, almost to a man, people whose ideas of what was right were formed in strict Protestant homes. That is the new frame of reference that the scholarship of these years, 1890-1918, needs.

Within this new frame of reference, Herron's case is extreme and very useful, for it helps define the limits of progressive reform. When Herron criticized competition, excess wealth, and the generally callous ethic of the business world, he was speaking in a way that both his friends and enemies could understand. They loved and hated him accordingly, but they both listened. But when he began to criticize churches, and men, and colleges, and governments with increasing vehemence, seeming to take no notice of exceptions, he began to lose his audience. Americans since the rise of Arminianism in the middle eighteenth century had long believed that reform was possible, that people could act, and that some kind of free choice could lead men and societies toward salvation. As speech after speech became publicized, and people realized the increasingly unbalanced nature of Herron's analyses, he began to lose his support. When he openly violated the sexual mores of a still devoutly Protestant moral code, they dropped him precipitately. In effect, they told him that he was right in finding the times out of joint, and in criticizing business and politics; he was wrong in indulging in blanket denunciation, in advocating state socialism, and in breaking moral laws. The next two decades, with their campaigns for marriage reform, prohibition, anti-trust and other laws, would repeat this 
pattern within narrower limits: to be successful, an American reformer had to believe in Christian morals, right and wrong, and reform from within. Herron was destroyed by the very moral elements he helped to energize, and the movement went on without him.

\title{
Museum Notes
}

\author{
by John Phipps, \\ Museum Director
}

A scale model WW II Landing Craft has been recently acquired by the museum. The model was built in 1945 by German prisoners of war and is perfect in every detail. The full-sized craft, an LCVP (landing craft, vehicle, personnel) was thirty-six feet in length, had a very shallow draft and was able to maneuver close enough to a beach so that vehicles and men could unload when the ramp was lowered. It was armed with two fifty $\mathrm{mm}$ guns mounted in wells near the stern. These guns provided cover fire for the landing of troops and materiel.

The donor, retired Navy Capt., Don A. Foster of Des Moines, was in command of a Navy boat repair and maintenance group at Coronado, $\mathrm{Ca}$. in 1945. This unit repaired and rehabilitated this type of landing craft. A number of P.O.W.S were assigned to the group but due to the rules of war, could not be used to further the war effort. These men were given the opportunity to work on projects such as this model to keep themselves occupied.

The model will be on display soon-probably third floor, South, off the Rotunda.

$$
\text { \# \# }
$$

It has been said that "history repeats itself"-an excellent example is the trend in men's hair styles. These seem to have gone full circle, and the hair and beard styles of a hundred years ago are now the "in" thing.

With the advent of labial hirsutism among males perhaps the moustache cup may again make a comeback. At any rate the museum has, after many years, been fortunate enough to acquire two very fine specimens which are now on display in the Civil History Room-second floor, West. 
Copyright of Annals of Iowa is the property of State of Iowa, by \& through the State Historical Society of Iowa and its content may not be copied or emailed to multiple sites or posted to a listserv without the copyright holder's express written permission. However, users may print, download, or email articles for individual use. 